IZA DP No. 10298

Vocational vs. General Education and Employment over the Life-Cycle: New Evidence from PIAAC

Franziska Hampf

Ludger Woessmann

October 2016 


\title{
Vocational vs. General Education and Employment over the Life-Cycle: New Evidence from PIAAC
}

\author{
Franziska Hampf \\ Ifo Institute, University of Munich \\ Ludger Woessmann \\ University of Munich, Ifo Institute, CESifo \\ and IZA
}

Discussion Paper No. 10298

October 2016

\author{
IZA \\ P.O. Box 7240 \\ 53072 Bonn \\ Germany \\ Phone: +49-228-3894-0 \\ Fax: +49-228-3894-180 \\ E-mail: iza@iza.org
}

Any opinions expressed here are those of the author(s) and not those of IZA. Research published in this series may include views on policy, but the institute itself takes no institutional policy positions. The IZA research network is committed to the IZA Guiding Principles of Research Integrity.

The Institute for the Study of Labor (IZA) in Bonn is a local and virtual international research center and a place of communication between science, politics and business. IZA is an independent nonprofit organization supported by Deutsche Post Foundation. The center is associated with the University of Bonn and offers a stimulating research environment through its international network, workshops and conferences, data service, project support, research visits and doctoral program. IZA engages in (i) original and internationally competitive research in all fields of labor economics, (ii) development of policy concepts, and (iii) dissemination of research results and concepts to the interested public.

IZA Discussion Papers often represent preliminary work and are circulated to encourage discussion. Citation of such a paper should account for its provisional character. A revised version may be available directly from the author. 


\section{ABSTRACT}

\section{Vocational vs. General Education and Employment over the Life-Cycle: New Evidence from PIAAC*}

It has been argued that vocational education facilitates the school-to-work transition but reduces later adaptability to changing environments. Using the recent international PIAAC data, we confirm such a trade-off over the life-cycle in a difference-in-differences model that compares employment rates across education type and age. An initial employment advantage of individuals with vocational compared to general education turns into a disadvantage later in life. Results are strongest in apprenticeship countries that provide the highest intensity of industry-based vocational education.

JEL Classification: J24, J64, 120

Keywords: vocational education, apprenticeship, employment, life-cycle, PIAAC

Corresponding author:

Ludger Woessmann

Ifo Institute for Economic Research at the University of Munich

Poschingerstr. 5

81679 Munich

Germany

E-mail: woessmann@ifo.de

\footnotetext{
* We would like to thank Thijs Bol, Eric Hanushek, Guido Schwerdt, Simon Wiederhold, and participants at the ROA workshop on "Human Capital over the Life Cycle" in Maastricht for their comments. Financial support by the Leibniz Competition for the research project "Acquisition and Utilization of Adult Skills" (SAW-2015-GESIS-2) is gratefully acknowledged.
} 


\section{Introduction}

Around the world, there is an increasing interest in expanded vocational education as a way to get youth quickly and effectively into the labor market by endowing them with occupationspecific skills. Earlier analysis of labor markets in the 1990s, however, suggested possible adverse impacts of vocational education on employment opportunities later in life due to limited adaptability to technological and structural change (Hanushek et al. (2016)). With the significant transformation of labor markets over the past two decades including such factors as globalization, digitalization, technological change, altered training programs, and reforms of social security systems, it is important to revisit the potential efficacy of expanding vocational education in today's economic environment.

The ramifications of the deep changes that have occurred on labor markets for the employment effects of vocational education over the life-cycle are not obvious. On the one hand, the structural changes brought about by globalization and the rapid technological changes stemming from automation and digitalization (e.g., Autor, Dorn, and Hanson (2015)) may make the obsolescence of occupation-specific skills over the life-cycle even more pronounced (cf. Krueger and Kumar (2004)). On the other hand, reduced options of generous early retirement schemes in the social security systems of many countries may dampen the incidence of reduced employment at older ages. For example, in Germany the entitlement age for early retirement after twelve months of unemployment has been gradually raised from 60 to 63 years since 2006, and the terms of early retirement have become less generous. ${ }^{1}$

This paper uses the Programme for the International Assessment of Adult Competencies (PIAAC), conducted in 2011-12, to estimate the employment effects of vocational vs. general

\footnotetext{
${ }^{1}$ In fact, the share of those retiring before age 65 (61) among all retirees in Germany has declined from 75 (56) percent in 1995 to 57 (25) percent in 2012 (Deutsche Rentenversicherung Bund (2015)).
} 
education over the life-cycle on modern labor markets in a sample of 16 countries. To address concerns of selection into types of education, we employ the difference-in-differences model introduced by Hanushek et al. (2016) that compares employment rates across age for people with general and vocational education and make use of the individual skill measures available in PIAAC, among others, to account for potential differential changes in selectivity over time.

Our results confirm a strong trade-off between early advantages and late disadvantages in employment for individuals with vocational education. But there is strong heterogeneity depending on the specific institutional structure of schooling and work-based training in a country. While no significant pattern is detected in the six countries without sizeable vocational systems, the declining age-employment pattern of individuals with vocational education is found across the ten countries with vocational systems, and it is strongest in countries with widely developed apprenticeship systems where industry is directly involved in education. In these apprenticeship countries, the cross-over age by which individuals with a general education have higher employment probabilities is as low as age $44 .^{2}$

\section{The PIAAC Data}

Collected between August 2011 and March 2012, PIAAC was developed by the OECD to survey the skills of a representative sample of adults aged 16-65 in each participating country. For our purposes, PIAAC provides internationally comparable data on individuals’ type of

\footnotetext{
${ }^{2}$ For prior international analysis of vocational education and the school-to-work transition, see, e.g., Shavit and Müller (1998), Ryan (2001), and Zimmermann et al. (2013). Apart from the cross-country evidence in Hanushek et al. (2016), country-specific examples of labor-market analyses beyond the entry phase that show consistent age patterns by education type include Cörvers et al. (2011) for Germany, the Netherlands, and Great Britain, Weber (2014) for Switzerland, and Brunello and Rocco (2016) for Great Britain. While Stenberg and Westerlund (2015) and Golsteyn and Stenberg (2016) also find such a pattern for Sweden, Hall (2016) is an exception that does not find a significant pattern based on the pilot of a Swedish reform in 1988-93 that extended upper-secondary vocational programs by one year and increased their general content.
} 
education, labor-market status, and background variables in 16 countries. ${ }^{3}$ Following the classification of the extent and intensity of vocationalization of education systems in Hanushek et al. (2016), six of these countries (Ireland, Japan, Korea, Spain, United Kingdom, and the United States) are “non-vocational countries” with limited vocational systems, whereas ten countries are "vocational countries" with significant vocational systems. Among the latter, three countries (Austria, Denmark, and Germany) are “apprenticeship countries” with a substantial share of combined school and work-based vocational programs. The Czech Republic is also classified as a "non-school based vocational country" with some (albeit smaller) share of workplace training. In addition, six of the vocational countries (Australia, Finland, France, the Netherlands, Norway, and Sweden) have mostly school-based vocational sectors.

Our sample includes all males aged 16 to 65 who completed at least secondary education and are not currently in education. ${ }^{4}$ The type of education is derived from responses to an internationally harmonized background questionnaire. For individuals with secondary education, the PIAAC data provide a variable indicating whether a respondent's highest level of education is vocationally oriented. For individuals with tertiary education, we follow Hanushek et al. (2016) and Brunello and Rocco (2015) in classifying tertiary-type B programs (ISCED 5B) that focus on practical, technical, or occupational skills for direct labor-market entry as vocational.

Apart from the education type, PIAAC provides detailed tests of individuals' cognitive skills in numeracy, literacy, and "problem solving in technology-rich environments.” These skill measures have been shown to have substantial returns on the labor market (Hanushek et al. (2015)) and allow us to account for differential selectivity into education type by age. Test scores

\footnotetext{
${ }^{3}$ Among the remaining eight PIAAC countries, the Russian data have issues of representativeness, Canada and Estonia do not provide data on educational attainment in the Public Use File, and Belgium, Cyprus, Italy, Poland, and the Slovak Republic do not provide consistent data on the type of (vocational or general) education.

${ }^{4}$ The restriction to males with their historically stable aggregate labor-force participation patterns during prime age circumvents concerns raised about our identification by cohort-specific selection into work by females.
} 
are normalized to have mean zero and standard deviation one within each country. Apart from the richer testing of skills, PIAAC also provides substantially larger sample sizes per country than the International Adult Literacy Survey (IALS) of the mid-1990s, so that our full sample of 29,452 individuals is almost twice as large as in the IALS study by Hanushek et al. (2016). ${ }^{5}$

\section{Empirical Model}

Our focus is on the impact of vocational vs. general education types on employment over the life-cycle, with our main hypothesis being that any relative labor-market advantage of vocational over general education decreases with age. As developed in Hanushek et al. (2016), our baseline model is a simple difference-in-differences approach that compares the age-employment patterns of workers of the two education types within each country:

$$
E_{i}=\alpha_{0}+\alpha_{1} A_{i}+\alpha_{2} A_{i}^{2}+\beta_{1} G_{i}+\beta_{2} G_{i} \cdot A_{i}+X_{i} \gamma+\mu_{c}+\varepsilon_{i}
$$

where $E_{i}$ is an indicator capturing whether individual $i$ is employed (in paid work during the last week); age $A$ and its square capture the normal age-employment pattern in the economy; $G_{i}$ is an indicator for general (as opposed to vocational) education type; $X$ is a vector of control variables including years of schooling and skills; and $\mu_{c}$ are country fixed effects.

Our main coefficient of interest is $\beta_{2}$, which captures the differential impact of general relative to vocational education on employment with each year of age. ${ }^{6}$ In addition, $\beta_{1}$ measures the initial employment probability of general relative to vocational education (normalized to age 16 in the empirical application). While we doubt that $\beta_{1}$ adequately captures the impact of

\footnotetext{
${ }^{5}$ Further papers using the PIAAC data to study education and labor-market outcomes include Levels, van der Velden, and Allen (2014), Brunello and Rocco (2015), Broecke, Quintini, and Vandeweyer (2016), Forster, Bol, and van de Werfhorst (2016), Falck, Heimisch, and Wiederhold (2016), and Kahn (2016).

${ }^{6}$ See Hanushek et al. (2016) for deeper analysis of functional form which corroborates the simple linear-in-age interaction model.
} 
general education because it implicitly includes any selectivity into education types not captured by $X$, the identifying assumption for $\beta_{2}$ is the standard assumption of the difference-indifferences approach that the selectivity of people into general vs. vocational education (conditional on $X$ ) does not vary over time. Hanushek et al. (2016) provide extensive tests of this assumption, and we also address it in our analysis below.

\section{Employment Effects of Education Type over the Life-Cycle}

Our results in Table 1 indicate that there is indeed a strong trade-off of employment patterns by education type over the life-cycle. Initially, individuals completing vocational education programs have higher employment probabilities. But with increasing age, this advantage declines and ultimately turns around into an employment advantage of individuals completing general education programs (see also the simple descriptive pattern in Figure 1). Using the sample of ten vocational countries, the first column of Table 1 shows the simplest model that conditions only on country fixed effects, a quadratic in age, and years of schooling. At age 16, the employment probability of persons with a vocational education is 10.0 percentage points higher. But with every 10 years of age, this declines significantly by 3.2 percentage points, which is even larger than the 2.1 percentage points found in the equivalent specification of Hanushek et al. (2016) for the mid-1990s. The interacted specification implies that starting with age 48, persons with a general education have higher employment probability.

The main concern with identification from the age gradient in relative employment in this difference-in-differences approach is that within countries, selectivity into the two education types may have changed over time. As a first check on this possibility, column 2 adds the PIAAC literacy score and its interaction with age. On the one hand, this inclusion captures any change in selectivity that is reflected in differences in observed adult skills. On the other hand, 
these skills could in part be endogenous to the work history, thereby taking out more of the identifying variation than it should. In any event, while the association of literacy with employment indeed increases with age, the main pattern of results remains unchanged, with a slightly reduced coefficient on the education type-age interaction.

While the inclusion of literacy scores follows the analysis with the IALS test in Hanushek et al. (2016), PIAAC in fact provides considerably richer testing of skills which allows us to estimate our main equation conditional on the different domains of cognitive skills tested in PIAAC. When we add the PIAAC numeracy score in addition to the literacy score (column 3), literacy in fact loses significance, which is fully captured by numeracy. However, our qualitative results do not change. ${ }^{7}$ As another control for potential differential selectivity into education over time, column 4 adds controls for the education level of respondents' mothers and its interaction with age. These turn out insignificant and hardly change our substantive results. ${ }^{8}$

To account for potential effects of the aggregate composition of the labor force, column 5 adds the percentage of each ten-year age cohort completing general education in each country; results are hardly affected. ${ }^{9}$ In this main specification, for each 10 years of age, the relative employment chances of those with a general education increase by 2.2 percentage points relative to those with a vocational education, which is effectively the same as found in the base specification of Hanushek et al. (2016) for the mid-1990s.

As another approach to address possible selection issues, column 6 shows results of a model using propensity-score matching to compare individuals with a vocational education only to

\footnotetext{
${ }^{7}$ Despite the high correlation between literacy and numeracy (0.85), our results are effectively unchanged when including only numeracy or when using the average of literacy and numeracy. Interestingly, the new PIAAC domain of "problem solving in technology-rich environments" (not available in France and Spain) does not enter our employment equation significantly (individually or jointly with the other domains) and does not affect our results.

${ }^{8}$ The same holds for father's education and parents' highest education, which are missing more observations.

${ }^{9}$ The age pattern of employment by education type is also robust to adding the average skill scores of individuals with the particular education type by country and ten-year age cohort, as in Hanushek et al. (2016).
} 
observationally similar individuals with a general education. We use nearest-neighbor matching which matches each individual with vocational education to one individual with general education based on age, years of schooling, literacy and numeracy scores, and mother's education, so that the estimate is only identified from common support between the two groups. While this reduces the number of observations by 35 percent, our main result in fact becomes stronger, indicating that it is not driven by observations off the common support.

A final concern is selectivity at young ages because some young people are still in the education system, particularly in general programs. Thus, columns 7 and 8 restrict the sample to persons at least 20 and 30 years of age, respectively. In fact, the age pattern of employment by education type gets stronger in these reduced samples (in contrast to Hanushek et al. (2016)).

\section{Heterogeneity across Countries}

As indicated, countries differ widely in the treatment intensity of their aggregate institutional vocationalization. While the previous results were restricted to vocational countries, the first column of Table 2 shows that the main results also hold in the full sample of 16 countries, albeit at reduced coefficient size. In fact, column 2 shows that the pattern is not at all visible in the nonvocational countries, with effectively no employment differences across education types.

By contrast, results are substantially stronger in the countries with non-school based vocational systems (column 4) and, in particular, in the countries with extensive apprenticeship systems (column 5) whose substantial industry-based education provides more vocational experience (cf. Wolter and Ryan (2011)). The cross-over age from which on employment is higher for general than for vocational education is as low as 44 on average across the apprenticeship countries. In fact, despite the smaller sample sizes, the main pattern is significantly visible in all three apprenticeship countries (columns 6-8), with the Austrian results 
providing confirmation in a country that had not participated in IALS. The overall pattern across country groups is consistent with the employment effects of education types increasing with the treatment intensity of occupation-specific education in the vocational system. ${ }^{10}$

\section{Conclusions}

Using recent data on labor markets in a large sample of countries, we aim to provide a deeper understanding of the merits and limitations of different education types for employment in a globalized era. We find strong evidence that a life-cycle perspective is important: While individuals who completed vocational education programs initially have better employment opportunities than individuals who completed general education programs, this pattern turns around at older ages. The estimated impact of education type on the age-employment profile is consistent with vocational education improving the transition from schooling to work but reducing adaptability of older workers to economic change. This pattern is particularly pronounced in countries with apprenticeship systems, whose emphasis on industry-based education may provide the strongest treatment intensity of vocationalization. Our results suggest caution about policies that concentrate just on the current employment situation and ignore the dynamics of growing economies.

${ }^{10}$ These results suggest that the opposing interpretation in Forster, Bol, and van de Werfhorst (2016) may stem from peculiarities in their standardized index of vocational systems, as well as their inclusion of countries with unclear identification of education types in PIAAC. 


\section{References}

Autor, David H., David Dorn, and Gordon H. Hanson. 2015. "Untangling trade and technology: Evidence from local labour markets." Economic Journal 125, no. 584: 621-646.

Broecke, Stijn, Glenda Quintini, and Marieke Vandeweyer. 2016. "Wage inequality and cognitive skills: Re-opening the debate." NBER Working Paper 21965. Cambridge, MA: National Bureau of Economic Research.

Brunello, Giorgio, and Lorenzo Rocco. 2015. "The effects of vocational education on adult skills and wages: What can we learn from PIAAC?" OECD Social, Employment and Migration Working Papers 168. Paris: OECD.

Brunello, Giorgio, and Lorenzo Rocco. 2016. "The labour market effects of academic and vocational education over the life cycle: Evidence from two British cohorts." Journal of Human Capital: forthcoming.

Cörvers, Frank, Hans Heijke, Ben Kriechel, and Harald Pfeifer. 2011. "High and steady or low and rising? Life-cycle earnings patterns in vocational and general education." ROA Research Memorandum ROA-RM-2011/7. Maastricht: Research Centre for Education and the Labour Market.

Deutsche Rentenversicherung Bund. 2015. Rentenversicherung in Zeitreihen. Berlin: Deutsche Rentenversicherung Bund.

Falck, Oliver, Alexandra Heimisch, and Simon Wiederhold. 2016. "Returns to ICT skills." CESifo Working Paper 5720. Munich: CESifo.

Forster, Andrea G., Thijs Bol, and Herman G. van de Werfhorst. 2016. "Vocational education and employment over the life cycle." Sociological Science 3: 473-494.

Golsteyn, Bart, and Anders Stenberg. 2016. "Earnings over the life course: General versus vocational education." Maastricht University, Mimeo.

Hall, Caroline. 2016. "Does more general education reduce the risk of future unemployment? Evidence from an expansion of vocational upper secondary education." Economics of Education Review 52: 251-271.

Hanushek, Eric A., Guido Schwerdt, Simon Wiederhold, and Ludger Woessmann. 2015. "Returns to skills around the world: Evidence from PIAAC." European Economic Review 73: 103-130.

Hanushek, Eric A., Guido Schwerdt, Ludger Woessmann, and Lei Zhang. 2016. "General education, vocational education, and labor-market outcomes over the life-cycle." Journal of Human Resources: forthcoming.

Kahn, Lawrence M. 2016. "Permanent jobs, employment protection and job content." IZA Discussion Paper 9961. Bonn: Institute for the Study of Labor.

Krueger, Dirk, and Krishna B. Kumar. 2004. "Skill-specific rather than general education: A reason for US-Europe growth differences?" Journal of Economic Growth 9, no. 2: 167-207.

Levels, Mark, Rolf van der Velden, and Jim Allen. 2014. "Educational mismatches and skills: New empirical tests of old hypotheses." Oxford Economic Papers 66, no. 4: 959-982. 
Ryan, Paul. 2001. "The school-to-work transition: A cross-national perspective." Journal of Economic Literature 39, no. 1: 34-92.

Shavit, Yossi, and Walter Müller, eds. 1998. From school to work: A comparative study of educational qualifications and occupational destinations. Oxford: Clarendon Press.

Stenberg, Anders, and Olle Westerlund. 2015. "The long-term earnings consequences of general vs. specific training of the unemployed." IZA Journal of European Labor Studies 4, no. 1: 126.

Weber, Sylvain. 2014. "Human capital depreciation and education level." International Journal of Manpower 35, no. 5: 613-642.

Wolter, Stefan C., and Paul Ryan. 2011. "Apprenticeship." In Handbook of the Economics of Education, Vol. 3, edited by Eric A. Hanushek, Stephen Machin, and Ludger Woessmann. Amsterdam: North Holland: 521-576.

Zimmermann, Klaus F., Costanza Biavaschi, Werner Eichhorst, Corrado Giulietti, Michael J. Kendzia, Alexander Muravyev, Janneke Pieters, Núria Rodríguez-Planas, and Ricarda Schmidl. 2013. "Youth unemployment and vocational training." Foundation and Trends in Microeconomics 9, no. 1-2: 1-157. 
Figure 1: Employment by Age and Education Type in Apprenticeship Countries

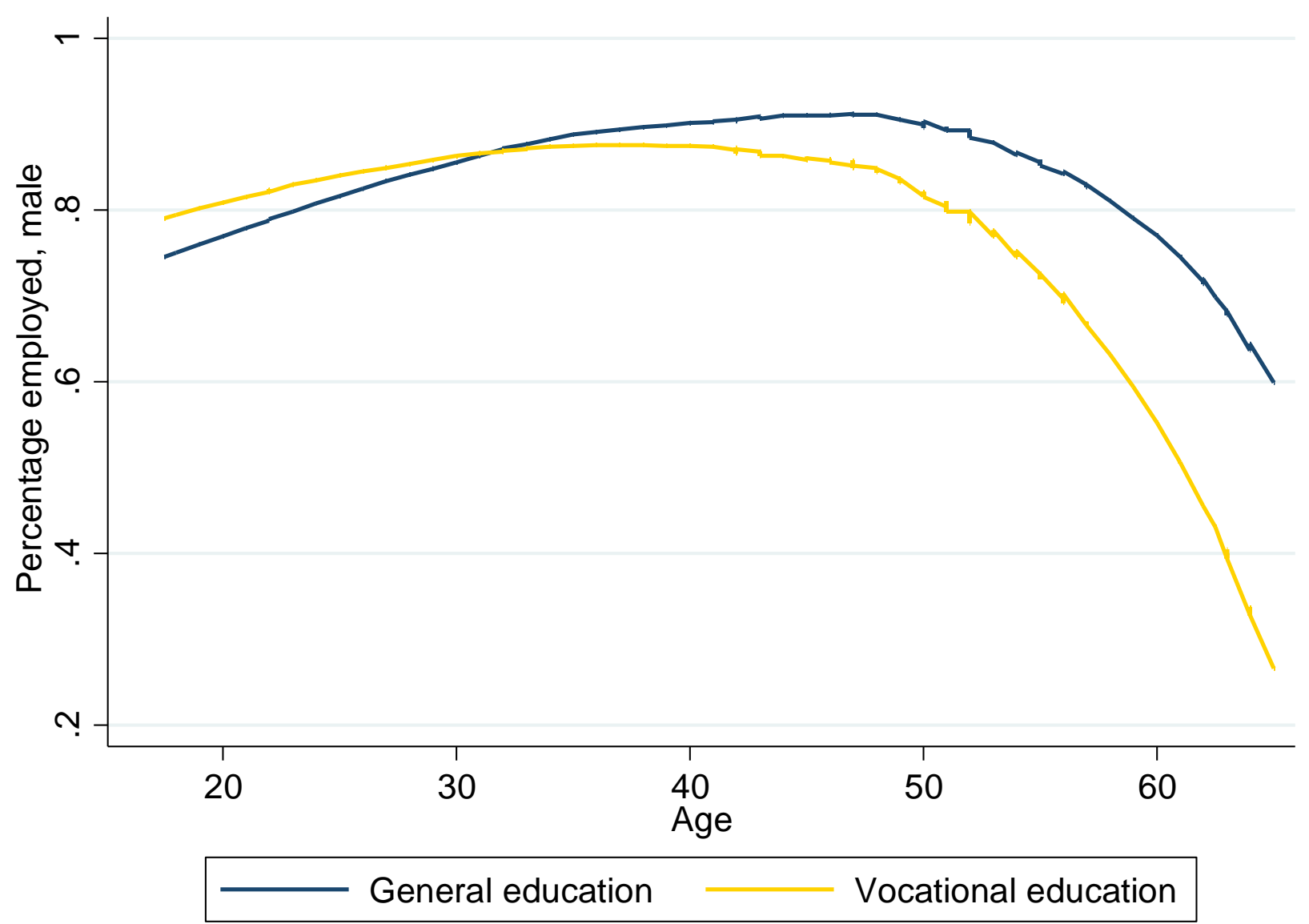

Notes: Sample includes all males who completed at least secondary education and are currently not students in the three "apprenticeship countries" (Austria, Denmark, and Germany). Smoothed scatterplot using locally weighted regressions (Stata lowess). Data source: PIAAC. 
Table 1: Vocational vs. General Education and Employment over the Life-Cycle in PIAAC

\begin{tabular}{|c|c|c|c|c|c|c|c|c|}
\hline & (1) & (2) & (3) & (4) & (5) & $\begin{array}{c}\text { (6) } \\
\text { Propensity- } \\
\text { score matching }\end{array}$ & $\begin{array}{c}(7) \\
20+\text { age } \\
\text { sample }\end{array}$ & $\begin{array}{c}(8) \\
30+\text { age } \\
\text { sample }\end{array}$ \\
\hline General education & $\begin{array}{c}-0.100^{* * *} \\
(0.017)\end{array}$ & $\begin{array}{c}-0.090^{* * *} \\
(0.018)\end{array}$ & $\begin{array}{c}-0.085^{* * *} \\
(0.018)\end{array}$ & $\begin{array}{c}-0.082^{* * *} \\
(0.019)\end{array}$ & $\begin{array}{c}-0.084^{* * *} \\
(0.018)\end{array}$ & $\begin{array}{c}-0.090^{* * *} \\
(0.027)\end{array}$ & $\begin{array}{c}-0.093^{* * *} \\
(0.018)\end{array}$ & $\begin{array}{c}-0.135^{* * *} \\
(0.026)\end{array}$ \\
\hline General education x Age & $\begin{array}{c}0.032^{* * *} \\
(0.006)\end{array}$ & $\begin{array}{l}0.024^{* * *} \\
(0.006)\end{array}$ & $\begin{array}{l}0.022^{* * *} \\
(0.006)\end{array}$ & $\begin{array}{l}0.021^{* * *} \\
(0.006)\end{array}$ & $\begin{array}{c}0.022^{* * *} \\
(0.006)\end{array}$ & $\begin{array}{c}0.027^{* * *} \\
(0.009)\end{array}$ & $\begin{array}{l}0.025^{* * *} \\
(0.006)\end{array}$ & $\begin{array}{c}0.034^{* * *} \\
(0.008)\end{array}$ \\
\hline Age & $\begin{array}{l}0.270^{* * *} \\
(0.013)\end{array}$ & $\begin{array}{l}0.260^{* * *} \\
(0.013)\end{array}$ & $\begin{array}{l}0.257^{* * *} \\
(0.013)\end{array}$ & $\begin{array}{l}0.255^{* * *} \\
(0.015)\end{array}$ & $\begin{array}{l}0.260^{* * *} \\
(0.013)\end{array}$ & $\begin{array}{l}0.260^{* * *} \\
(0.015)\end{array}$ & $\begin{array}{l}0.252^{* * *} \\
(0.013)\end{array}$ & $\begin{array}{c}0.453^{* * *} \\
(0.027)\end{array}$ \\
\hline $\operatorname{Age}^{2}$ & $\begin{array}{c}-0.066^{* * *} \\
(0.002)\end{array}$ & $\begin{array}{c}-0.062^{* * *} \\
(0.002)\end{array}$ & $\begin{array}{c}-0.062^{* * *} \\
(0.002)\end{array}$ & $\begin{array}{c}-0.062^{* * *} \\
(0.003)\end{array}$ & $\begin{array}{c}-0.063^{* * *} \\
(0.002)\end{array}$ & $\begin{array}{c}-0.062^{* * *} \\
(0.003)\end{array}$ & $\begin{array}{c}-0.062^{* * *} \\
(0.002)\end{array}$ & $\begin{array}{c}-0.091^{* * *} \\
(0.004)\end{array}$ \\
\hline Years of schooling & $\begin{array}{l}0.021^{* * *} \\
(0.002)\end{array}$ & $\begin{array}{l}0.016^{* * *} \\
(0.002)\end{array}$ & $\begin{array}{l}0.015^{* * *} \\
(0.002)\end{array}$ & $\begin{array}{l}0.015^{* * *} \\
(0.002)\end{array}$ & $\begin{array}{l}0.015^{* * *} \\
(0.002)\end{array}$ & $\begin{array}{l}0.020^{* * *} \\
(0.003)\end{array}$ & $\begin{array}{l}0.015^{* * *} \\
(0.002)\end{array}$ & $\begin{array}{c}0.017^{* * *} \\
(0.002)\end{array}$ \\
\hline Literacy score & & $\begin{array}{c}0.001 \\
(0.009)\end{array}$ & $\begin{array}{l}-0.002 \\
(0.017)\end{array}$ & $\begin{array}{l}-0.000 \\
(0.017)\end{array}$ & $\begin{array}{l}-0.003 \\
(0.017)\end{array}$ & $\begin{array}{c}0.028 \\
(0.022)\end{array}$ & $\begin{array}{l}-0.008 \\
(0.017)\end{array}$ & $\begin{array}{l}-0.017 \\
(0.025)\end{array}$ \\
\hline Literacy score x Age & & $\begin{array}{l}0.014^{* * *} \\
(0.003)\end{array}$ & $\begin{array}{c}0.002 \\
(0.006)\end{array}$ & $\begin{array}{c}0.002 \\
(0.006)\end{array}$ & $\begin{array}{c}0.002 \\
(0.006)\end{array}$ & $\begin{array}{c}-0.007 \\
(0.008)\end{array}$ & $\begin{array}{c}0.004 \\
(0.006)\end{array}$ & $\begin{array}{c}0.007 \\
(0.008)\end{array}$ \\
\hline Numeracy score & & & $\begin{array}{c}0.006 \\
(0.017)\end{array}$ & $\begin{array}{c}0.003 \\
(0.017)\end{array}$ & $\begin{array}{c}0.007 \\
(0.017)\end{array}$ & $\begin{array}{l}-0.002 \\
(0.021)\end{array}$ & $\begin{array}{c}0.011 \\
(0.017)\end{array}$ & $\begin{array}{c}0.029 \\
(0.025)\end{array}$ \\
\hline Numeracy score x Age & & & $\begin{array}{l}0.014^{* *} \\
(0.006)\end{array}$ & $\begin{array}{l}0.014^{* *} \\
(0.006)\end{array}$ & $\begin{array}{l}0.014^{* *} \\
(0.006)\end{array}$ & $\begin{array}{l}0.017^{* *} \\
(0.008)\end{array}$ & $\begin{array}{l}0.012^{* *} \\
(0.006)\end{array}$ & $\begin{array}{c}0.007 \\
(0.008)\end{array}$ \\
\hline $\begin{array}{l}\text { Share of country cohort with } \\
\text { general education }\end{array}$ & & & & & $\begin{array}{l}-0.133^{* *} \\
(0.066)\end{array}$ & $\begin{array}{l}-0.125 \\
(0.080)\end{array}$ & $\begin{array}{l}-0.144^{* *} \\
(0.066)\end{array}$ & $\begin{array}{l}0.178^{*} \\
(0.093)\end{array}$ \\
\hline $\begin{array}{l}\text { Mother's education ( } 2 \text { indicators } \\
\text { and their interaction with age) }\end{array}$ & & & & yes & & & & \\
\hline Country fixed effects & yes & yes & yes & yes & yes & yes & yes & yes \\
\hline Observations & 18,938 & 18,938 & 18,938 & 18,372 & 18,938 & 12,374 & 18,745 & 15,691 \\
\hline Countries & 10 & 10 & 10 & 10 & 10 & 10 & 10 & 10 \\
\hline$R^{2}$ (adj.) & 0.138 & 0.146 & 0.149 & 0.148 & 0.149 & 0.122 & 0.150 & 0.175 \\
\hline
\end{tabular}

Notes: Linear probability model. Dependent variable: individual is employed. Sample includes males aged 16 to 65 with at least secondary education in the 10 vocational countries. Age variable subtracted by 16 and divided by 10 . Regressions weighted by sampling weights, giving same weight to each country. Robust standard errors in parentheses. ${ }^{* * *} \mathrm{p}<0.01,{ }^{* *} \mathrm{p}<0.05,{ }^{*} \mathrm{p}<0.1$. Data source: PIAAC. 
Table 2: Heterogeneity across Country Groups with Different Vocational Intensity

\begin{tabular}{|c|c|c|c|c|c|c|c|c|}
\hline & (1) & $(2)$ & (3) & (4) & (5) & $(6)$ & (7) & (8) \\
\hline & All & Non-vocational & Vocational & Non-school based & \multicolumn{4}{|c|}{ Apprenticeship countries } \\
\hline & countries & countries & countries & vocational countries & All & Austria & Denmark & Germany \\
\hline General education & $\begin{array}{c}-0.063^{* * *} \\
(0.014)\end{array}$ & $\begin{array}{c}-0.001 \\
(0.024)\end{array}$ & $\begin{array}{c}-0.084^{* * *} \\
(0.018)\end{array}$ & $\begin{array}{c}-0.123^{* * *} \\
(0.032)\end{array}$ & $\begin{array}{c}-0.134^{* * *} \\
(0.035)\end{array}$ & $\begin{array}{c}-0.083 \\
(0.062)\end{array}$ & $\begin{array}{c}-0.110^{* *} \\
(0.046)\end{array}$ & $\begin{array}{c}-0.201^{* * *} \\
(0.067)\end{array}$ \\
\hline General education x Age & $\begin{array}{c}0.019^{* * *} \\
(0.005)\end{array}$ & $\begin{array}{l}-0.000 \\
(0.009)\end{array}$ & $\begin{array}{l}0.022^{* * *} \\
(0.006)\end{array}$ & $\begin{array}{l}0.041^{* * *} \\
(0.011)\end{array}$ & $\begin{array}{c}0.049^{* * *} \\
(0.012)\end{array}$ & $\begin{array}{c}0.064^{* * *} \\
(0.022)\end{array}$ & $\begin{array}{l}0.036^{* *} \\
(0.015)\end{array}$ & $\begin{array}{c}0.043^{*} \\
(0.022)\end{array}$ \\
\hline Controls & yes & yes & yes & yes & yes & yes & yes & yes \\
\hline Country fixed effects & yes & yes & yes & yes & yes & yes & yes & yes \\
\hline Observations & 29,452 & 10,514 & 18,938 & 8,040 & 6,004 & 1,719 & 2,365 & 1,920 \\
\hline Countries & 16 & 6 & 10 & 4 & 3 & 1 & 1 & 1 \\
\hline
\end{tabular}

Notes: Linear probability model. All models include the same controls as column 5 of Table 1. Dependent variable: individual is employed. Sample includes males aged 16 to 65 with at least secondary education. See section 2 for country groups. Age variable subtracted by 16 and divided by 10 . Regressions weighted by sampling weights, giving same weight to each country. Robust standard errors in parentheses. ${ }^{* * *} \mathrm{p}<0.01,{ }^{* *} \mathrm{p}<0.05{ }^{*}{ }^{*} \mathrm{p}<0.1$. Data source: PIAAC. 